\title{
Tietoa maatiloista ja niiden toiminnasta - Maatalouslaskenta 2010 ja tuotantomenetelmätutkimus
}

\author{
Jaana Kyyrä ja Pasi Mattila \\ Tike - Maa- ja metsätalousministeriön tietopalvelukeskus, PL 310, 00023 Valtioneuvosto, \\ jaana.kyyra@mmmtike.fi
}

\section{Tiivistelmä}

Maatalouslaskenta on kaikki maatilat kattava maatalouden rakennetutkimus, jolla kerätään tietoa maatilojen tuotantovälineistä ja toiminnasta. Maatalouslaskenta toimeenpannaan kymmenen vuoden välein maailmanlaajuisena tilastotutkimuksena FAO:n suositusten mukaisesti. EU:n ja Euroopan talousalueen maissa maatalouslaskentaa ohjaa maatalouden rakennetutkimukseen liittyvä EU-lainsäädäntö. Maatalouslaskentojen välillä suoritetaan 2-3 vuoden välein suppeampia rakennetutkimuksia, joissa tiedot kerätään vain osalta maatiloista. Maatalouslaskennalla saatava tieto on tärkeää aineistoa maatalous- ja elintarvikealan poliittisessa päätöksenteossa ja tutkimuksessa. Suomessa maatalouslaskennat ja rakennetutkimukset toteuttaa Tike - Maa- ja metsätalousministeriön tietopalvelukeskus.

Maatalouslaskenta 2010:n tiedonkeruu tehdään syksyn 2010 ja talven 2011 aikana kaikille Suomen noin 65000 maatilalle. Osa tiedoista saadaan maatalousalan tilastoista ja rekistereistä, mutta paljon asioita jää kysyttäviksi suoraan viljelijöiltä. Tiedonkeruun alussa viljelijöillä on mahdollisuus antaa tiedot sähköisellä lomakkeella Internetin kautta. Maatilat, jotka eivät vastaa sähköisesti, täyttävät paperilomakkeen, jonka tiedot kerätään puhelinhaastatteluilla. Tike tarkistaa ja julkaisee kerätyt tiedot sekä toimittaa ne EU:n tilastotoimistolle (Eurostat).

Maatalouslaskennan ja tuotantomenetelmätutkimuksen kaikissa maissa kerättävät tiedot on määritelty EU:n asetuksessa. Lisäksi mukaan voidaan ottaa tarpeellisiksi katsottuja kansallisia kysymyksiä. Kysyttävien asioiden määrä on kuitenkin pidettävä kohtuullisena, jotta viljelijä voi vastata kyselyyn mahdollisimman helposti ja nopeasti.

Maatalouden ympäristövaikutuksiin ja eläinten hyvinvointiin liittyvän tiedon tarve on kasvanut. Siksi EU on päättänyt tehdä maatalouslaskennan yhteydessä erillisen tuotantomenetelmätutkimuksen, jossa osalta tiloista kerätään yksityiskohtaista tietoa peltoviljelyn ja eläintenhoidon menetelmistä. Suomessa tuotantomenetelmätutkimukseen otetaan noin 15000 tilaa.

Vuoden 2010 maatalouslaskenta on kymmenes Suomessa toteutettava maatalouslaskenta ja samalla vietetään maatalouslaskennan 100-vuotisjuhlaa. Suomen ensimmäinen maatalouslaskenta tehtiin vuonna 1910 eli jo ennen itsenäistymistä. Vuonna 1995 alkaneen EU-jäsenyyden aikana Suomessa on tehty EU-lainsäädännön mukaisia maatalouden rakennetutkimuksia, joista vuoden 2000 maatalouslaskenta on laajin. Maataloustilastoissa näkyvät Suomen maatalouden ja yhteiskunnan muutokset. Sadan vuoden aikana kerätty tieto auttaa hahmottamaan maatalouden menneitä vaiheita ja tulevaa kehitystä.

\section{Asiasanat}

Maatalous, talous, rakenne, tilasto 


\section{Maatalouslaskennan historia}

Vuonna 2010 tulee kuluneeksi 100 vuotta Suomen ensimmäisestä maatalouslaskennasta. Vuoden 2010 laskenta on kymmenes Suomessa toteutettu laskenta. Ensimmäinen maatalouslaskenta toteutettiin vuonna 1910, jolloin Suomi oli vielä Venäjään kuuluva suuriruhtinaskunta. Vuonna 1920 toteutettiin itsenäisen Suomen ensimmäinen laskenta. Seuraava laskenta tehtiin vuosina 1929-1939. Tässä laskennassa noudatettiin YK:n elintarvike- ja maatalousjärjestö FAO:n edeltäjän kansainvälisen maatalousinstituutin suosituksia. Maatalouslaskenta toteutettiin myös välirauhan ja jatkosodan aikana vuonna 1941 erittäin vaikeista olosuhteista huolimatta. Laskennan loppuunsaattaminen venyi vuoden 1942 puolelle, ja sodan vuoksi tulokset olivat osin epäluotettavia.

Ennen vuoden 1950 laskentaa oli astunut voimaan laki maataloustilastoista. Tässä laskennassa kerättiin tiedot yli kahden hehtaarin tiloilta. Alle kahden hehtaarin tilojen tiedot kerättiin väestölaskennan yhteydessä. Vuonna 1959 laskenta suoritettiin kahdessa vaiheessa. Peruslaskenta käsitti yli 0,25 hehtaarin tilat. Tätä pienempien tilojen tiedot kerättiin otantana. Vuoden 1969 laskennassa ensimmäistä kertaa kysyttiin maatilojen työvoimaa koskevia tietoja. Tuloksista selvisi, että maatiloilla työskenteli paljon vähemmän nuoria miehiä kuin nuoria naisia. Vuonna 1980 laskentaa ei tehty, vaan tiedot pellonkäytöstä ja kotieläinten lukumääristä kerättiin maatilarekisteritiedustelujen yhteydessä kahtena eri vuonna. Vuoden 1990 laskenta oli viimeinen tilakäynnein toteutettu maatalouslaskenta. Vuoden 2000 laskenta oli ensimmäinen Suomen EU-jäsenyyden aikainen laskenta. Tietoja saatiin sekä maataloushallinnon rekistereistä että keräämällä viljelijöiltä.

Maataloustilastoissa näkyvät Suomen maatalouden ja yhteiskunnan muutokset (kuvat 1 ja 2). Sadan vuoden aikana kerätty tieto auttaa hahmottamaan maatalouden menneitä vaiheita ja tulevaa kehitystä.

\section{Vuoden 2010 maatalouslaskenta}

Vuoden 2010 laskennassa kerättävät tiedot ovat pääosin samat kuin aiemmissa maatalouden rakennetutkimuksissa, jotka on tehty 2-3 vuoden välein osalle maatiloista. EU ja ETA-maissa maatalouslaskentaa ohjaa maatalouden rakennetutkimukseen liittyvä lainsäädäntö (asetus 1166/2008 EY). Kaikilta tiloilta kysytään tietoja tilan työvoimasta, sukupolvenvaihdoksesta, tietotekniikasta, peltojen kastelusta sekä maa- tai puutarhatalouden yhteydessä harjoitettavasta muusta yritystoiminnasta. Uutena EU:n asettamana aiheena on tilalla tapahtuva energian tuotanto uusiutuvia energianlähteitä käyttäen.

Vuoden 2010 laskennassa viljelijöillä on ensimmäistä kertaa mahdollisuus antaa tiedot sähköisesti Internetin välityksellä. Maatalouslaskennan verkkopalvelu on toteutettu samalla tekniikalla kuin maataloustukien haku Internetissä. Palvelu on pyritty rakentamaan niin, että vastaaminen olisi mahdollisimman helppoa. Keskeneräisen lomakkeen voi esimerkiksi tallentaa ja jatkaa lomakkeen täyttämistä myöhemmin. Lomakkeen täyttämistä yksinkertaistaa se, että sähköinen lomake näyttää vain ne kysymykset, joihin kyseisen tilan täytyy vastata. Paperilomakkeessa esimerkiksi on omat sivut maatilan työvoimalle omistusmuodoittain. Paperilomakkeella on siis tässä kohdassa kolme sivua joista kuitenkin kukin tila täyttää vain yhden. Sähköisessä palvelussa valitaan ensin omistusmuoto, minkä jälkeen sähköinen lomake näyttää vain kyseessä olevan omistusmuodon mukaiset työvoimakysymykset. Sähköisen palvelun toivotaan helpottavan viljelijöiden vastaamista myös siksi, että vastaaminen ei ole samalla lailla aikaan sidottu kuin puhelinhaastattelut. Tilat, jotka eivät vastaa sähköiseen palveluun, täyttävät paperilomakkeen, jonka tiedot haastattelija kysyy puhelimitse. Tiedonkeruu alkaa syyskuussa 2010 ja kestää noin puoli vuotta.

Maatalouslaskennan sähköinen vastaaminen noudattaa yhteiskunnan yleistä kehitystä: asiointi siirtyy internetiin. Maatalouslaskentaa varten luotavaa vastaussovellusta aiotaan hyödyntää muissakin Tiken tiedonkeruissa. Tulevaisuudessa viljelijä voi katsoa aiemmin eri tiedonkeruissa sähköisesti antamiaan tietoja ja käyttää niitä pohjana vastatessaan uusiin kyselyihin. Tiken ulkopuolisin voimin toteutettuihin puhelinhaastatteluihin verrattuna sähköinen vastaaminen nopeuttaa ja tehostaa tiedonkeruuta. Sähköisen lomakkeen toiminnot mahdollistavat paperilomaketta kattavamman ohjeistuksen, joka onkin tarpeen, koska vastaaja ei voi kysyä epäselviä asioita haastattelijalta. Sähköiseen vastaamiseen toki sisältyy mahdollisuus kysyä neuvoja Tikestä internetin kautta tai puhelimitse. 
Keväällä 2009 noin 6000 tilaa jätti tukihakemuksen sähköisesti. Moninkertaisen määrän viljelijöitä uskotaan täyttävän maatalouslaskennan sähköisen lomakkeen, koska kokemukset sähköisestä tukihausta ovat olleet hyvät eikä laskennan tietojen luovuttaminen vaikuta tilan tuloihin. Maatalouslaskennan sähköisestä vastaamisesta saadun kokemuksen toivotaan myös edistävän sähköisen tukihaun käyttöä jatkossa.

\section{Tuotantomenetelmätutkimus}

EU:n päätöksen mukaisesti vuoden 2010 maatalouslaskennan yhteydessä tehdään ensimmäisen kerran tuotantomenetelmätutkimus, jolla kerätään tietoa ympäristöön ja eläinten hyvinvointiin liittyvistä asioista kuten peltojen muokkauksesta ja talviaikaisesta kasvipeitteestä, peltojen kastelusta, lannan varastoinnista ja levittämisestä sekä karjarakennuksista ja karjan laiduntamisesta. Kansallisena kysymyksenä tuotantomenetelmätutkimuksessa on eri lähteistä saatavan energian käyttö maatiloilla (sähkö, polttoaineet ym.). Näistä aihepiireistä tarvitaan entistä enemmän tietoa, jotta maatalous- ja ympäristöpolitiikalla pystyttäisiin mm. vähentämään kasvihuonekaasupäästöjä ja vesistöjen ravinnekuormitusta. Ympäristöön ja eläinten hyvinvointiin liittyvä päätöksenteko vaatii sekä luonnontieteisiin, yhteiskuntatieteisiin että taloustieteisiin perustuvaa tutkimustietoa. Näin voidaan etsiä ratkaisuja, jotka ovat kaikilta osin toimivia ja kestäviä niin yksittäisen maatilan kuin koko yhteiskunnan tasolla. Tike tuottaa tilastotietoa kaikkien maataloutta ja maaseutua tutkivien tieteenalojen käyttöön.

EU:n vaatimana tietona tuotantomenetelmätutkimuksessa on $\mathrm{mm}$. ilmoitettava kastellut viljelykasvit ja käytetyn kasteluveden määrä tilakohtaisesti. Koska viljelijän olisi todennäköisesti vaikea arvioida kasteluveden määrää, nämä tiedot lasketaan yhteistyössä Maa- ja elintarviketalouden tutkimuskeskuksen (MTT) puutarhatuotannon asiantuntijoiden kanssa käyttäen säätietoihin perustuvaa mallinnusta.

Maatalouslaskenta kattaa kaikki maatilat, mutta tuotantomenetelmätutkimuksen tiedot kerätään vain noin 15000 tilalta. Osa EU- ja ETA-maista kerää laskennan ja tuotantomenetelmätutkimuksen tiedot erikseen, mutta toiset, kuten Suomi, yhdistävät nämä kaksi tiedonkeruuta. Suomessa tuotantomenetelmätutkimus toteutetaan siten, että laskennan lomakkeesta tehdään kaksi versiota. Tuotantomenetelmätutkimukseen osallistuvat tilat saavat lomakkeen, johon tuotantomenetelmätutkimuksen kysymykset on lisätty maatalouslaskennan kysymysten joukkoon aihepiireittäin. Loput tilat saavat lomakkeen, joka sisältää vain maatalouslaskennan kysymykset.

\section{Rekistereiden hyödyntäminen maatalouslaskennassa}

Maatalouslaskennassa hyödynnetään rekistereistä saatavaa tietoa mahdollisimman paljon. Tilastolaki velvoittaa käyttämään ensisijaisesti olemassa olevaa tietoa. Maatalouslaskennassa käytetään viljelijöiden tukihaun yhteydessä luovuttamia tietoja. Tieto kysytään viljelijältä vain, jos sitä ei saada muualta.

EU-jäsenyyden myötä maataloushallinnon tietojärjestelmiin on koottu mittava määrä tietoa, jota voidaan hyödyntää tehokkaasti maataloustilastojen laadinnassa. Tällaisia tietojärjestelmiä ovat mm. tukisovellus, peltolohkorekisteri, luomurekisteri sekä lammas- ja vuohirekisteri. Tilastollisia rekistereitä ovat mm. maatilarekisteri ja puutarharekisteri. Noin puolet laskennan tietosisällöstä saadaan hallinnon tietojärjestelmistä, esimerkiksi tilakohtaiset tiedot kasvien viljelypinta-aloista ja kotieläinten lukumääristä. Käytännön menettely on sellainen, että hallinnon rekisteritiedot kopioidaan tilastolliseen rekisteriin, jota käytetään varsinaisena lähteenä maatalouslaskennassa. Tuotantomenetelmätutkimuksessa tarvittavia yksityiskohtaisia tietoja peltoviljelyn ja kotieläintuotannon menetelmistä ei rekistereistä saada, joten ne kysytään viljelijöiltä.

\section{Linkkejä maataloustilastoihin}

Tike - Maa- ja metsätalousministeriön tietopalvelukeskus http://www.mmmtike.fi/fi/

Eurostat, Agricultural statistics http://epp.eurostat.ec.europa.eu/portal/page/portal/agriculture/introduction

FAO World Census of Agriculture http://www.fao.org/economic/ess/world-census-of-agriculture/en/ 


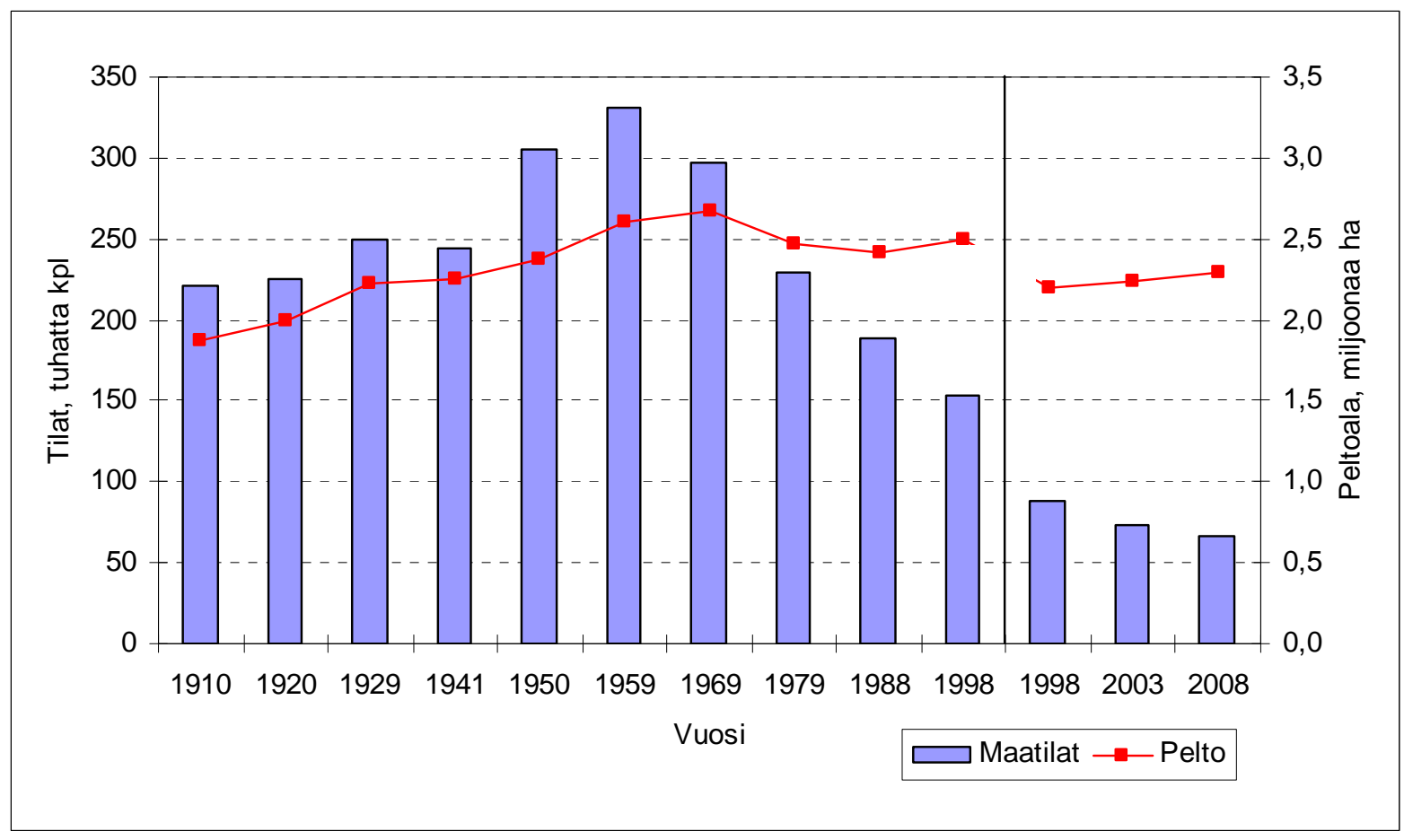

Kuva 1. Maatilojen lukumäärä ja peltoala Suomessa. Tilastoinnissa tapahtuneen muutoksen vuoksi vuonna 1998 luvut putoavat hieman alemmalle tasolle. Vuoden 1998 tiedot esitetään sekä vanhan että uuden tilastoinnin mukaisina. Lähde: Tike.

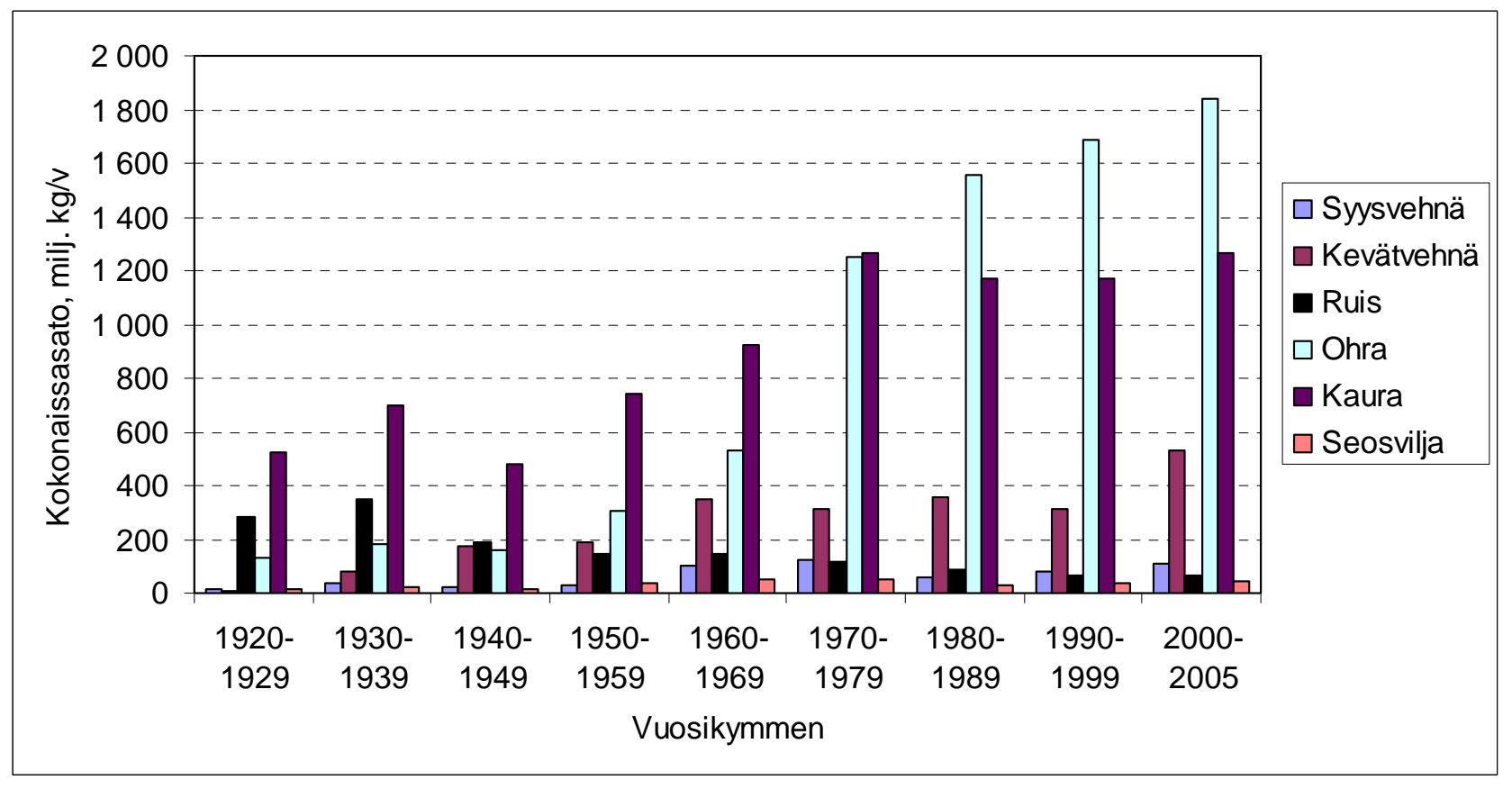

Kuva 2. Viljantuotanto Suomessa. Vuosittaisen kokonaissadon keskiarvot viljalajeittain ja vuosikymmenittäin. Lähde: Tike. 